\title{
Absorption Kinetics and Subcellular Fractionation of Zinc in Winter Wheat in Response to Nitrogen Supply
}

\author{
Zhaojun Nie, Peng Zhao, Jia Wang, Jinfeng Li and Hongen Liu * \\ Department of Resources and Environment, Resources and Environment College, Henan Agricultural University, Zhengzhou, \\ China
}

Nitrogen $(\mathrm{N})$ is critical for zinc $(\mathrm{Zn})$ absorption into plant roots; this in turn allows for Zn accumulation and biofortification of grain in winter wheat (Triticum aestivum L.), an important food crop. However, little is known about root morphology and subcellular Zn distribution in response to $\mathrm{N}$ treatment at different levels of $Z n$ supply. In this study, two nutrient solution culture experiments were conducted to examine $\mathrm{Zn}$ accumulation, $\mathrm{Zn}$ absorption kinetics, root morphology, and Zn subcellular distribution in wheat seedlings pre-cultured with different $\mathrm{N}$ concentrations. The results showed positive correlations between $\mathrm{N}$ and $\mathrm{Zn}$ concentrations, and $\mathrm{N}$ and $\mathrm{Zn}$ accumulation, respectively. The findings suggested that an increase in $\mathrm{N}$ supply enhanced root absorption and the root-to-shoot transport of $Z n$. Nitrogen combined with the high $Z n\left(Z n_{10}\right)$ treatment increased the $\mathrm{Zn}$ concentration and consequently its accumulation in both shoots and roots. The maximum influx rate $\left(V_{\max }\right)$, root length, surface area, and volume of 14 -d-old seedlings,

Edited by:

Richard William Bell,

Murdoch University, Australia

Reviewed by:

Susan Tandy

ETH Zurich, Switzerland Brian M. Waters, University of Nebraska Lincoln,

United States

*Correspondence: Hongen Liu liuhongen7178@126.com

Specialty section:

This article was submitted to

Plant Nutrition,

a section of the journal

Frontiers in Plant Science

Received: 20 February 2017 Accepted: 03 August 2017

Published: 18 August 2017

Citation:

Nie Z, Zhao P, Wang J, Li J and Liu H (2017) Absorption Kinetics and Subcellular Fractionation of Zinc in Winter Wheat in Response to Nitrogen

Supply. Front. Plant Sci. 8:1435 doi: 10.3389/fpls.2017.01435 and root growth from 7 to $14 \mathrm{~d}$ in the medium $\mathrm{N}\left(\mathrm{N}_{7.5}\right)$ treatment were higher, but the Michaelis constant $\left(K_{m}\right)$ and minimum equilibrium concentrations $\left(C_{m i n}\right)$ in this treatment were lower than those in the low $\left(\mathrm{N}_{0.05}\right)$ and high $\left(\mathrm{N}_{15}\right) \mathrm{N}$ treatments, when $\mathrm{Zn}$ was supplied at a high level $\left(Z n_{10}\right)$. Meanwhile, there were no pronounced differences in the above root traits between the $N_{0.05} Z n_{0}$ and $N_{7.5} Z n_{10}$ treatments. An increase in $N$ supply decreased $Z n$ in cell walls and cell organelles, while it increased $Z n$ in the root soluble fraction. In leaves, an increase in $N$ supply significantly decreased $Z n$ in cell walls and the soluble fraction, while it increased $Z n$ in cell organelles under Zn deficiency, but increased $\mathrm{Zn}$ distribution in the soluble fraction under medium and high $\mathrm{Zn}$ treatments. Therefore, a combination of medium $\mathrm{N}$ and high $\mathrm{Zn}$ treatments enhanced $\mathrm{Zn}$ absorption, apparently by enhancing Zn membrane transport and stimulating root development in winter wheat. An increase in $\mathrm{N}$ supply was beneficial in terms of achieving a balanced distribution of Zn subcellular fractions, thus enhancing $\mathrm{Zn}$ translocation to shoots, while maintaining normal metabolism.

Keywords: absorption kinetics, nitrogen, root morphology, subcellular fractionation, zinc

\section{INTRODUCTION}

Zinc (Zn) deficiency is a common nutritional disorder in humans, affecting billions of people worldwide, particularly those in developing countries, where diets are often based on cereal grains with low Zn concentration (Welch and Graham, 2004; Cakmak et al., 2010). In China, Zn deficiency affects $\sim 100$ million people who live in rural areas (Ma et al., 2008). 
In many countries, wheat is the main dietary component and the most important source of both calories and protein (Cakmak, 2008). In China, the Northern Winter Wheat Region contributes about $70 \%$ of national wheat production (Zhuang, 2003). However, $\mathrm{Zn}$ deficiency is common in the calcareous soils of Northern China, and this is becoming a limitation for the improvement of $\mathrm{Zn}$ content in wheat grain for many Chinese provinces (Liu, 1994). Thus, attempts to increase the $\mathrm{Zn}$ concentration of wheat grain, when crops are grown in $\mathrm{Zn}$-deficient soils, is an important area of agricultural research (Bouis, 2003; White and Broadley, 2009). The breeding of novel genotypes with high grain $\mathrm{Zn}$ content and applying $\mathrm{Zn}$-rich fertilizers are two applicable and sustainable strategies for the long-term improvement of grain Zn content (Bouis, 2003; Pfeiffer and McClafferty, 2007; Cakmak, 2008). Furthermore, studies report that an increase in nitrogen $(\mathrm{N})$ supply to plants shows potential for agronomic Zn biofortification of wheat (Cakmak et al., 2010; Xue et al., 2012). Furthermore, N combined with Zn supply is more effective in increasing grain $\mathrm{Zn}$ content than single $\mathrm{N}$ or Zn supply, especially when wheat is cultured in $\mathrm{Zn}$ deficient soils. Kutman et al. (2010) pointed out that both soil and foliar $\mathrm{N}$ application improves $\mathrm{Zn}$ concentration in durum wheat grain when $\mathrm{Zn}$ supply is adequately high. Li et al. (2015) also report that foliar $\mathrm{Zn}$ combined with $\mathrm{N}$ increased $\mathrm{Zn}$ concentration and bioavailability in wheat grain during a 2-year field experiment. These studies suggest that a combined N/Zn application might be a promising strategy for increasing grain $\mathrm{Zn}$ concentrations to address dietary $Z n$ deficiency.

Zinc concentration in wheat grain depends on physiological processes in plants, such as root uptake, root-to-shoot transport, phloem loading, remobilization of $\mathrm{Zn}$ from the source tissues into developing seeds, and deposition of $\mathrm{Zn}$ in the seed (Kutman et al., 2010). Grain proteins are reported to be contributed for the accumulation of $\mathrm{Zn}$ as there are highly positive correlations between seed protein and seed Zn (Peleg et al., 2008). Increasing the levels of $\mathrm{N}$ nutrition has been reported to enhance root uptake, root-to-shoot translocation, and remobilization of $\mathrm{Zn}$ in wheat (Cakmak et al., 2010; Erenoglu et al., 2011), while also increasing protein concentration in the grain. Meanwhile, a high $\mathrm{N}$ supply leads to the long term uptake of $\mathrm{Zn}$ resulting in increased $\mathrm{Zn}$ accumulation in grain, due to delayed senescence and thus an extended grain-filling period (Yang and Zhang, 2006).

The distribution of $\mathrm{Zn}$ at subcellular levels in plant tissues has received significant attention (Rathore et al., 1972; Chardonnens et al., 1999; Li et al., 2006; Pan et al., 2016), due to the importance of the subcellular localization of $\mathrm{Zn}$ relative to its functional role in cellular activities (Whatley et al., 1951). However, all these studies were carried out under conditions of excessive $\mathrm{Zn}$. Plants possess a range of detoxifying cellular mechanisms, such as storing $\mathrm{Zn}$ within cell walls or leaf vacuoles, which result intolerance to $\mathrm{Zn}$ stress ( $\mathrm{Li}$ et al., 2006). Meanwhile, little information is currently available on the subcellular distribution

Abbreviations: $V_{\max }$, maximum influx rate; $K_{\mathrm{m}}$, Michaelis constant; $C_{\min }$, minimum equilibrium concentrations; $\mathrm{N}$ nitrogen; $\mathrm{Zn}$, zinc. of $\mathrm{Zn}$ in plants that are cultured under conditions of deficient or sufficient $\mathrm{Zn}$ supply, especially combined with a varied $\mathrm{N}$ supply.

Excessive $\mathrm{N}$ fertilization in intensive agricultural areas results in severe environmental problems such as eutrophication, increased greenhouse gas emissions, and soil acidification, and has recently received greater attention in China (Zheng et al., 2004; Guo et al., 2010; Le et al., 2010). Policies related to increased levels of $\mathrm{N}$ application have been highlighted by the Department of Agriculture of China, in relation to the key target of balancing crop production and environmental protection.

Our previous studies showed that adequate $\mathrm{N}$ supply increases grain yield, total $\mathrm{Zn}$ accumulation, and $\mathrm{Zn}$ concentration in the different physiological parts of winter wheat under field conditions; of particular interest is the greater accumulation of $\mathrm{Zn}$ in grains as compared with other parts (Zhao et al., 2013, 2016). The aim of this study was to: (i) re-examine the influence of different levels of $\mathrm{N}$ and $\mathrm{Zn}$ application on $\mathrm{Zn}$ accumulation; (ii) to investigate $\mathrm{Zn}$ absorption kinetics influenced by different levels of $\mathrm{N}$ supply; and (iii) to investigate root morphology and Zn subcellular distribution in response to different levels of $\mathrm{N}$ supply, combined with $\mathrm{Zn}$ supply during hydroponic trials under greenhouse conditions.

\section{MATERIALS AND METHODS Greenhouse Conditions}

All experiments were performed in a greenhouse under controlled environmental conditions, using a light/dark regime of $14 / 10 \mathrm{~h}$, corresponding air temperatures of $22 / 18^{\circ} \mathrm{C}$, a photon flux density of $\sim 500 \mu \mathrm{mol} \mathrm{m}{ }^{-2} \mathrm{~s}^{-1}$, and a relative humidity of $\sim 65 \%$.

\section{Solution Culture}

Winter wheat (Triticum aestivum. cv Yunong202) seeds were disinfected in a solution of $0.5 \% \mathrm{NaClO}$ before being germinated in deionized water (resistivity $>18.25 \mathrm{M} \Omega . \mathrm{cm}$ at $25^{\circ} \mathrm{C}$ ) at $25^{\circ} \mathrm{C}$ for $5 \mathrm{~d}$. After germination, the seedlings were transferred to $4 \mathrm{~L}$ plastic containers of nutrient solutions consisting of $2.5 \mathrm{mM} \mathrm{K}_{2} \mathrm{SO}_{4}, 1 \mathrm{mM} \mathrm{KH} \mathrm{PO}_{4}, 2 \mathrm{mM} \mathrm{MgSO} \cdot 7 \mathrm{H}_{2} \mathrm{O}, 100 \mu \mathrm{M}$ ethylene diamine tetraacetic acid (EDTA)-Fe, $46 \mu \mathrm{M} \mathrm{H}_{3} \mathrm{BO}_{3}$, $9 \mu \mathrm{M} \mathrm{MnCl} 2 \cdot 4 \mathrm{H}_{2} \mathrm{O}, 0.3 \mu \mathrm{M} \mathrm{CuSO} \cdot 5 \mathrm{H}_{2} \mathrm{O}$, and $0.02 \mu \mathrm{M}$ $\left(\mathrm{NH}_{4}\right)_{6} \mathrm{Mo}_{7} \mathrm{O}_{24} \cdot 4 \mathrm{H}_{2} \mathrm{O}$. The final $\mathrm{pH}$ of the solution was adjusted to 6.0. Different amounts of $\mathrm{Zn}$ were added in the form of $\mathrm{ZnSO}_{4} \cdot 7 \mathrm{H}_{2} \mathrm{O}$, depending on the experimental or treatment group, and different $\mathrm{N}$ supplies were established through the addition of $\mathrm{Ca}\left(\mathrm{NO}_{3}\right)_{2} \cdot 4 \mathrm{H}_{2} \mathrm{O}$. Low $\mathrm{N}$ and medium $\mathrm{N}$ pots were supplemented with $\mathrm{CaCl}_{2} \cdot 2 \mathrm{H}_{2} \mathrm{O}$ to ensure adequate $\mathrm{Ca}$ concentrations. Quarter-strength and half-strength nutrient solutions were used during the first and second weeks, respectively. Subsequently, full-strength solutions were used until all seedlings were sampled. The solutions were refreshed every 3 d. All vessels used in the experiment were dipped in $5 \% \mathrm{HCl}$ for 1 week prior to use and were then washed with deionized water a minimum of three times. The water used for the preparation of nutrient solutions was deionized, and all chemical reagents were of analytical grade. 


\section{Absorption Kinetics and Subcellular Fractionation Experiments}

In the first experiment, 20 seedlings per pot were cultured in a nutrient solution with $0.5 \mathrm{mM}\left(\mathrm{N}_{0.5}\right.$, low $), 7.5 \mathrm{mM}\left(\mathrm{N}_{7.5}\right.$, medium), or $15 \mathrm{mM}\left(\mathrm{N}_{15}\right.$, high) $\mathrm{N}$ as well as $0 \mu \mathrm{M}\left(\mathrm{Zn}_{0}\right.$, without), $1 \mu \mathrm{M}\left(\mathrm{Zn}_{1}\right.$, medium), or $10 \mu \mathrm{M}$ ( $\mathrm{Zn}_{10}$, high) $\mathrm{Zn}$ supply. The roots of two seedlings were sampled and analyzed for morphological characteristics after cultivation for 7 and $14 \mathrm{~d}$, respectively. The shoots and roots of 14 plants were separately harvested after cultivation for $21 \mathrm{~d}$, oven-dried at $65^{\circ} \mathrm{C}$ and analyzed for dry weights and elemental concentrations. The separated parts of other wheat plants, comprising leaves, stems, and roots, were immediately frozen in liquid nitrogen and stored at $-20^{\circ} \mathrm{C}$ for further subcellular fractionation analysis.

The second experiment was a time course depletion experiment in which seedlings were pre-cultured in a nutrient solution for $21 \mathrm{~d}$ without $\mathrm{Zn}$ but with $\mathrm{N}_{7.5}$. To study the effects of varied $\mathrm{N}$ supply on the depletion of $\mathrm{Zn}$ from the nutrient solution, plants were supplied with $\mathrm{N}_{0.5}, \mathrm{~N}_{7.5}$, or $\mathrm{N}_{15}$ for the next $24 \mathrm{~h}$. To start the depletion experiment, the roots of the seedlings were washed in a solution containing $0.5 \mathrm{mM} \mathrm{CaSO}_{4}$ and $2 \mathrm{mM}$ 2- (N- morpholine) ethanesulfonic acid (MES) for $30 \mathrm{~min}$ and then transferred to flasks containing $300 \mathrm{~mL}$ of the absorption solution, which contained macronutrients, micronutrients, and $10 \mu \mathrm{M} \mathrm{ZnSO} 4 \cdot 7 \mathrm{H}_{2} \mathrm{O}$. The $\mathrm{Zn}$ concentration in $3 \mathrm{~mL}$ of nutrient solution was measured at 10 different time points $(0,0.5,1,2,4$, $6,8,10,12$, and $24 \mathrm{~h}$ ). Throughout the experiment, the volume of solution in the pots was kept constant by adding the respective $\mathrm{Zn}$-free nutrient solutions.

\section{Analysis of Root Morphological Characteristics}

Root length, root surface area, root volume, and average root diameter were determined from root images, using the root imaging analysis software WinRHIZO Version 2009 PRO (Regent Instruments, Quebec City, Canada).

\section{Tissue Fractionation}

Frozen materials were pretreated according to the method described by Weigel and Jäger (1980) and Li et al. (2006). A 2 -g portion of frozen leaf, stem, or root was placed into 50$\mathrm{mL}$ polypropylene centrifuge tubes and homogenized in $20 \mathrm{~mL}$ extraction buffer (50 mM Tris- $\mathrm{HCl}$ ( $\mathrm{pH} 7.5), 250 \mathrm{mM}$ sucrose, and $1.0 \mathrm{mM}$ dithioerythritol). The homogenate was centrifuged at $300 \times \mathrm{g}$ for $30 \mathrm{~s}$ and the residue constituted the cell wall fraction. The supernatant was then centrifuged at $10,000 \times \mathrm{g}$ for $30 \mathrm{~min}$ and the retained pellet formed the cell organelle fraction. The resultant supernatant solution (referred to as the soluble fraction, consisting mostly of vacuoles) was used in subsequent characterization studies as described. All steps were performed at $4^{\circ} \mathrm{C}$.

\section{Mineral Analysis}

For the $\mathrm{Zn}$ analysis, dry samples were ground and digested with $5 \mathrm{~mL}$ of $\mathrm{HNO}_{3}: \mathrm{HClO}_{4}(4: 1, \mathrm{v} / \mathrm{v})$. The cell wall and cell organelle fractions of tissues were transferred to $100 \mathrm{~mL}$ Erlenmeyer conical flasks containing deionized water, evaporated to dryness, and subjected to acid digestion as described above. The digested samples were diluted to $25 \mathrm{~mL}$ with deionized water and concentrations of $\mathrm{Zn}$ were determined by flame atomic absorption spectrophotometer (ZEEnit 700, Analytik Jena AG, Germany). The soluble fraction and solutions sampled from the depletion experiment were acidified with $\mathrm{HNO}_{3}$, and then determined using a flame atomic absorption spectrophotometer. For $\mathrm{N}$ analysis, dried and ground samples were digested with $\mathrm{H}_{2} \mathrm{SO}_{4}$ and $\mathrm{H}_{2} \mathrm{O}_{2}$, and the sample solution was determined for total $\mathrm{N}$ concentrations according to the Kjeldahl method, using a nitrogen autoanalyzer (BRAN LUEBBE AA3 Autoanalyzer, Germany). Measurements were checked for accuracy of $\mathrm{Zn}$ and $\mathrm{N}$ determination using certified standard reference materials, purchased from the National Center of Standard Material in China.

\section{Calculations and Statistical Analyses}

Zinc and $\mathrm{N}$ accumulation ( $\mu \mathrm{g}$ plant $^{-1}$ and $\mathrm{mg}$ plant $^{-1}$, respectively) were calculated from $\mathrm{Zn}$ and $\mathrm{N}$ concentrations, respectively, multiplied by the dry weight.

Zinc absorption kinetics were estimated using a modified Michaelis-Menten model (Barber, 1979):

$$
I_{n}=\frac{V_{\max }\left(C_{s}-C_{\min }\right)}{K+\left(C_{s}-C_{\min }\right)}
$$

where: $I_{\mathrm{n}}$ is the inflow rate at substrate concentration $C_{\mathrm{s}} ; C_{\mathrm{s}}$ is the substrate concentration in the root medium; $V_{\max }$ is the maximum influx rate at saturating substrate concentration; $C_{\min }$ is the minimum equilibrium concentration, meaning the substrate concentration in solution at which there is no net inflow $\left(I_{n}=0\right)$; and $K_{\mathrm{m}}$ is the Michaelis constant, equaling $C_{\mathrm{s}}-C_{\min }$, where $I_{\mathrm{n}}$ is $1 / 2$ of $V_{\max }$. The kinetic parameters of $\mathrm{Zn}$ including $V_{\max }\left(\mu \mathrm{mol} \mathrm{g}{ }^{-1}\right.$ root fresh weight $\left.[\mathrm{FW}] \mathrm{h}^{-1}\right), K_{\mathrm{m}}\left(\mu \mathrm{mol} \mathrm{L}{ }^{-1}\right)$, and $C_{\min }\left(\mu \mathrm{mol} \mathrm{L}^{-1}\right)$ were calculated based on the $\mathrm{Zn}$ depletion curve according to the method used by Jiang et al. (1995). Firstly, a quadratic curve between times and $\mathrm{Zn}$ concentration in solution is fitted using the non-linear regression procedure of Excel 2007:

$$
Y=a+b X+c X^{2}
$$

where: $Y$ represents $\mathrm{Zn}$ concentrations in solution at each time; and $X$ represents the depletion time. A negative derivative equation is then obtained through Equation (2):

$$
Y^{\prime}=-b-2 c X
$$

When $X=0, Y^{\prime}$ equals $-b$, meaning the maximum change rate of the $\mathrm{Zn}$ concentrations in solution. Thus, $V_{\max }$ is obtained through calculation:

$$
V_{\max }=\frac{-b \times v}{m}
$$

where: $\mathrm{v}$ is the volume of absorption solution; and $\mathrm{m}$ is the weight of dry root. When $Y^{\prime}$ equals $-b / 2$ in Equation (3), then $\mathrm{X}_{1}$ equals $-b / 4 c . K_{\mathrm{m}}$ is calculated by substituting the above $\mathrm{X}_{1}$ into the 
Equation (2). Finally, when $Y^{\prime}$ equals zero in Equation (3), then $\mathrm{X}_{2}$ equals $-b / 2 c$. $C_{\min }$ is also calculated by substituting the above $\mathrm{X}_{2}$ into the Equation (2).

The subcellular fractions of $\mathrm{Zn}$ were calculated as a percentage of total $\mathrm{Zn}$ in all fractions.

The significance of the effects of treatment and their interaction on the reported traits was evaluated using one-way or two-way analysis of variance (ANOVA), depending on the experimental design. The data are presented as the average of three replicates. Significant differences among means were determined, using Fisher's protected least significant difference (LSD) test at a $5 \%$ level $(P<0.05)$.

\section{RESULTS}

\section{Dry Weight of Shoots and Roots and Root-to-Shoot Ratios}

According to the results of two-way ANOVA, not only the $\mathrm{N}$ and $\mathrm{Zn}$ treatments, but also their interaction exerted significant effects $(P<0.05)$ on the dry weight of shoots and roots (Table S1). An increase in $\mathrm{N}$ supply significantly increased shoot and root dry weights at each $\mathrm{Zn}$ treatment, with the highest value in $\mathrm{N}_{15}$ (Table 1). However, the root-to-shoot ratio significantly decreased with increasing $\mathrm{N}$ supply. Increasing $\mathrm{Zn}$ supply significantly increased shoot dry weight in the $\mathrm{N}_{7.5}$ and $\mathrm{N}_{15}$ treatments, and root dry weight in the $\mathrm{N}_{15}$ treatment. When $\mathrm{N}$ was supplied at rates of $\mathrm{N}_{0.5}$ or $\mathrm{N}_{7.5}$, the root dry weights also increased with the $\mathrm{Zn}_{1}$ treatment. Root-to-shoot ratios were significantly increased by the $\mathrm{N}_{0.5} \mathrm{Zn}_{1}$ treatment, while the $\mathrm{N}_{7.5} \mathrm{Zn}_{10}$ treatment significantly decreased root-to-shoot ratios.

\section{$\mathrm{Zn}$ and $\mathrm{N}$ Concentrations and Their Accumulation}

Two-way ANOVA revealed significant interactive effects of $\mathrm{N}$ and $\mathrm{Zn}$ treatment on $\mathrm{Zn}$ concentrations and its accumulation in shoots and roots $(P<0.01$; Table $S 1)$. For each $\mathrm{N}$ treatment, increasing the $\mathrm{Zn}$ supply led to higher $\mathrm{Zn}$ concentrations and accumulation in shoots and roots. However, under $\mathrm{Zn}$ deficiency, increasing the $\mathrm{N}$ supply had no apparent effect on $\mathrm{Zn}$ concentration and accumulation in shoots and roots (Figure 1). In both $\mathrm{Zn}_{1}$ and $\mathrm{Zn}_{10}, \mathrm{Zn}$ concentration and accumulation in shoots were significantly increased by an increase in $\mathrm{N}$ supply (Figures 1A,C). Only in the $\mathrm{Zn}_{10}$ treatment did an increase in $\mathrm{N}$ supply significantly increase $\mathrm{Zn}$ concentration and accumulation in roots (Figures $\mathbf{1 B}, \mathbf{C}$ ).

The $\mathrm{N}$ and $\mathrm{Zn}$ treatments interacted significantly in their effects on $\mathrm{N}$ concentration and accumulation in shoots and roots $(P<0.01$; Table $\mathrm{S} 1)$. An increase in $\mathrm{N}$ supply resulted in marked increases in $\mathrm{N}$ concentration and accumulation in shoots and roots (Figure 2). At $\mathrm{N}_{0.5}$, only the $\mathrm{Zn}_{10}$ treatment significantly increased shoot $\mathrm{N}$ concentration. At $\mathrm{N}_{7.5}$, an increase in $\mathrm{Zn}$ supply significantly increased shoot $\mathrm{N}$ concentration and accumulation, and only the $\mathrm{Zn}_{1}$ treatment significantly increased root $\mathrm{N}$ concentration and accumulation. In $\mathrm{N}_{15}$, the $\mathrm{Zn}_{10}$ treatment resulted in higher shoot and root $\mathrm{N}$ concentrations and accumulation, while the $\mathrm{Zn}_{1}$ treatment significantly increased shoot $\mathrm{N}$ accumulation but decreased root $\mathrm{N}$ concentration.

There were significant positive relationships between shoot $\mathrm{N}$ and $\mathrm{Zn}$ concentration $\left(r=0.647^{\star *}\right)$, shoot $\mathrm{N}$ and $\mathrm{Zn}$ accumulation $\left(r=0.761^{* *}\right)$, root $\mathrm{N}$ and $\mathrm{Zn}$ accumulation $\left(r=0.445^{\star}\right)$, and plant $\mathrm{N}$ and $\mathrm{Zn}$ accumulation $\left(r=0.674^{\star \star}\right)$, respectively.

\section{Zn Absorption Kinetics}

In the time-course experiment, the depletion of $\mathrm{Zn}$ by plants was followed for $24 \mathrm{~h}$ under the three $\mathrm{N}$ treatments. $\mathrm{N}_{7.5}$ resulted in the highest level of $\mathrm{Zn}$ exhaustion in the solution after $1 \mathrm{~h}$, followed by $\mathrm{N}_{15} ; \mathrm{N}_{0.5}$ was the slowest to deplete $\mathrm{Zn}$ in the solution (Figure 3A). The values of $V_{\max }, K_{\mathrm{m}}$, and $C_{\min }$ were strongly dependent on the level of $\mathrm{N}$ supply $(P<0.05$; Table S2). The value of $V_{\max }$ was higher, and the values of $K_{\mathrm{m}}$ and $C_{\min }$ were lower in $\mathrm{N}_{7.5}$, compared to $\mathrm{N}_{0.5}$ and $\mathrm{N}_{15}$ (Figures 3B,C).

\section{Root Morphology}

As revealed by two-way ANOVA, the root length, root surface area, root volume, and root average diameter of 7 - and 14-dold seedlings were significantly affected by $\mathrm{N}$ and $\mathrm{Zn}$ treatments, and $\mathrm{N} \times \mathrm{Zn}$ interaction $(P<0.05$ or $P<0.01$; Table S3). In the 7-d-old seedlings, the $\mathrm{N}_{7.5}$ and $\mathrm{N}_{15}$ treatments exhibited a significantly decreased root length for each $\mathrm{Zn}$ treatment (Table 2). The root surface area was also significantly decreased by $\mathrm{N}_{7.5}$ and $\mathrm{N}_{15}$ in the $\mathrm{Zn}_{1}$ treatment, and decreased by $\mathrm{N}_{15}$ in the $\mathrm{Zn}_{10}$ treatment. The $\mathrm{N}_{15}$ treatment exhibited a larger root volume under $\mathrm{Zn}$ deficiency, but had a smaller root volume than $\mathrm{N}_{0.5}$ and $\mathrm{N}_{7.5}$ under the $\mathrm{Zn}_{1}$ and $\mathrm{Zn}_{10}$ applications. The $\mathrm{N}_{7.5}$ and $\mathrm{N}_{15}$ treatments significantly increased root average diameter with the $\mathrm{Zn}_{0}$ and $\mathrm{Zn}_{10}$ applications, compared to the $\mathrm{N}_{0.5}$ treatment. The

TABLE 1 | Shoot and root dry weights and root-to-shoot ratios of winter wheat (Triticum aestivum cv Yunong202) seedlings, pre-cultured with 0.5, 7.5 , or 15 mmol $\mathrm{N}$ L-1 in a nutrient solution with 0,1 , and $10 \mu \mathrm{mol} \mathrm{Zn} \mathrm{L}^{-1}$ supply for $21 \mathrm{~d}$.

\begin{tabular}{|c|c|c|c|c|c|c|c|c|c|}
\hline \multirow[t]{2}{*}{ N supply } & \multicolumn{3}{|c|}{ Shoot (g plant ${ }^{-1}$ ) } & \multicolumn{3}{|c|}{ Root (g plant ${ }^{-1}$ ) } & \multicolumn{3}{|c|}{ Root: shoot } \\
\hline & $\mathbf{Z n}_{0}$ & $\mathrm{Zn}_{1}$ & $\mathrm{Zn}_{10}$ & $\mathrm{Zn}_{0}$ & $\mathrm{Zn}_{1}$ & $\mathrm{Zn}_{10}$ & $\mathrm{Zn}_{0}$ & $\mathrm{Zn}_{1}$ & $\mathrm{Zn}_{10}$ \\
\hline $\mathrm{N}_{0.5}$ & $0.29 d$ & $0.31 d$ & $0.30 d$ & $0.16 d$ & $0.20 \mathrm{bc}$ & $0.16 d$ & $0.56 b$ & $0.63 a$ & $0.54 b$ \\
\hline $\mathrm{N}_{7.5}$ & $0.47 c$ & $0.60 \mathrm{~b}$ & $0.65 b$ & $0.17 d$ & $0.22 b$ & $0.17 \mathrm{~cd}$ & $0.37 c$ & $0.36 c$ & $0.27 d$ \\
\hline $\mathrm{N}_{15}$ & $0.61 b$ & $0.74 a$ & $0.76 a$ & $0.20 b$ & $0.25 a$ & $0.25 a$ & $0.33 \mathrm{~cd}$ & $0.33 \mathrm{~cd}$ & $0.33 \mathrm{~cd}$ \\
\hline
\end{tabular}

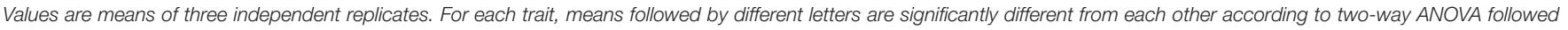
by least significant difference ( $L S D)$ multiple comparison $(P<0.05)$. 


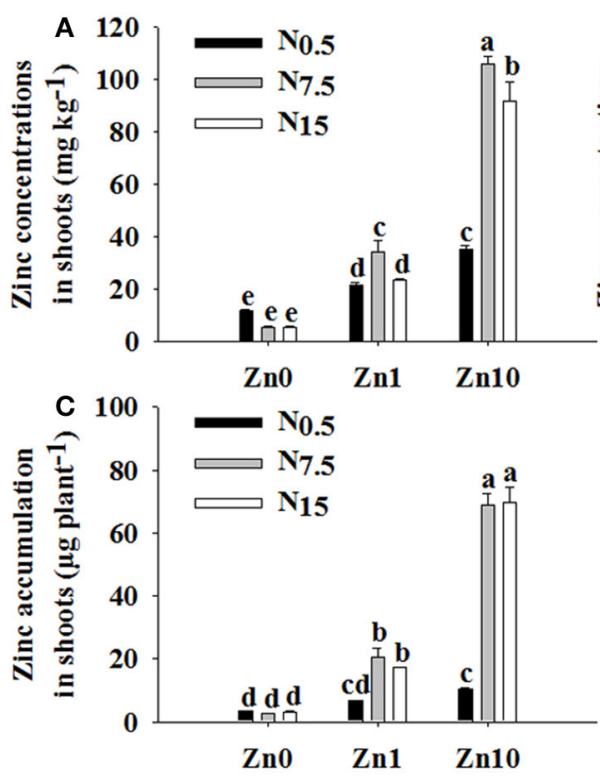

Zn treatment $\left(\mu \mathrm{mol} \mathrm{L}^{-1}\right)$

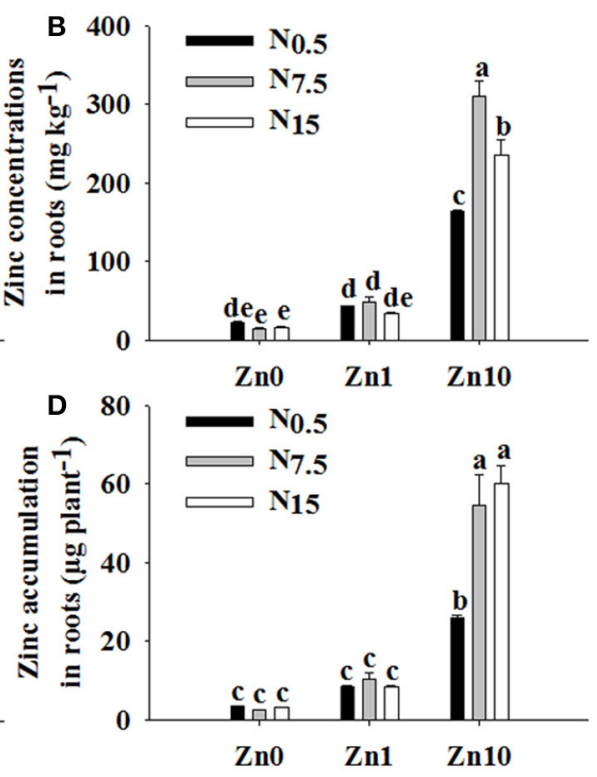

Zn treatment $\left(\mu \mathrm{mol} \mathrm{L} \mathbf{L}^{-1}\right)$

FIGURE 1 | Zinc concentrations in shoots (A) and roots (B) as well as Zn accumulation in shoots (C) and roots (D) of winter wheat (Triticum aestivum cv Yunong202) seedlings grown at $0.5,7.5$, or $15 \mathrm{mmol} \mathrm{N} \mathrm{L}{ }^{-1}$ in a nutrient solution with 0,1 , and $10 \mu \mathrm{mol} \mathrm{Zn} \mathrm{L}^{-1}$ supply. Values are means of three independent replicates. Error bars represent 1 SE. For each trait, means followed by different letters are significantly different from each other according to two-way ANOVA followed by least significant difference (LSD) multiple comparison $(P<0.05)$.

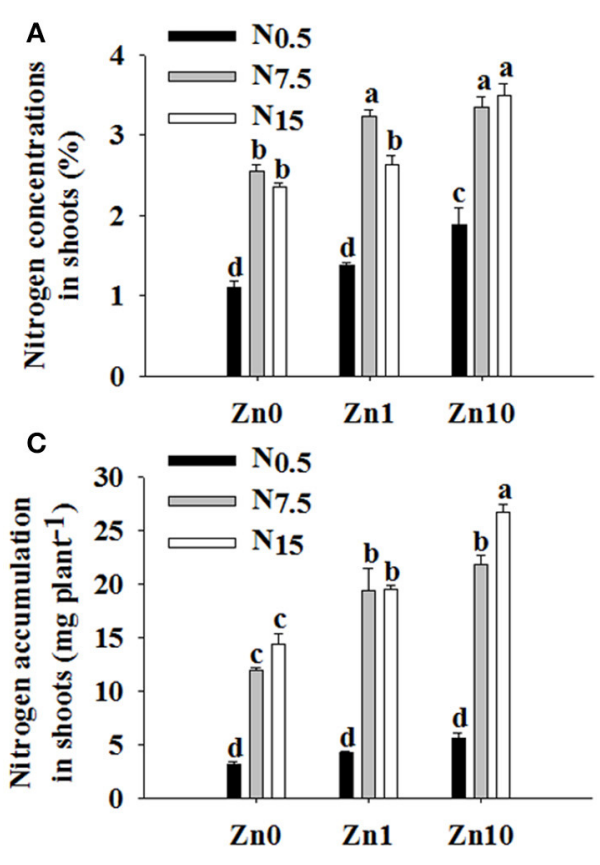

Zn treatment $\left(\mu \mathrm{mol} \mathrm{L} \mathbf{L}^{-1}\right)$
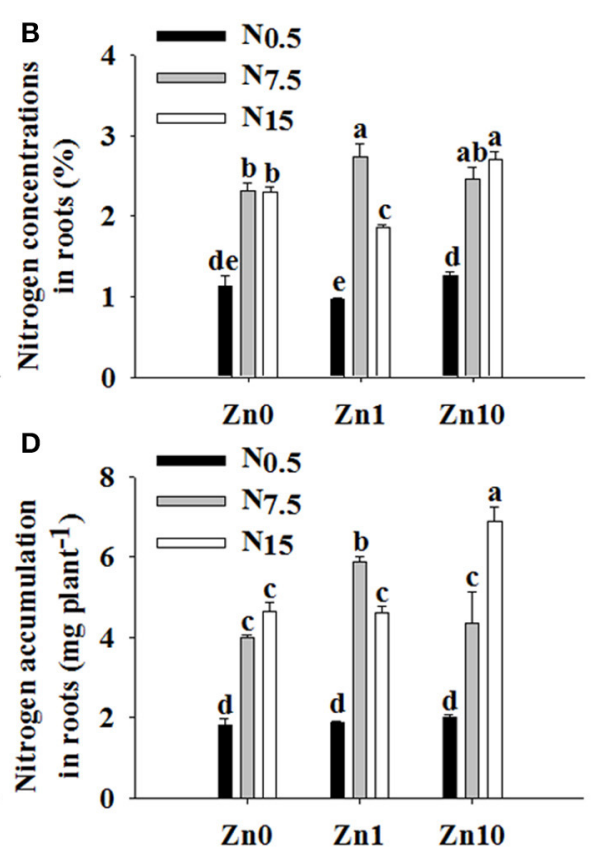

Zn treatment $\left(\mu \mathrm{mol} \mathrm{L} \mathbf{L}^{-1}\right)$

FIGURE 2 | Nitrogen concentrations in shoots (A) and roots (B) and N accumulation in shoots (C) and roots (D) of winter wheat (Triticum aestivum cv Yunong202) seedlings grown at $0.5,7.5$, or $15 \mathrm{mmol} \mathrm{N} \mathrm{L}{ }^{-1}$ in a nutrient solution with 0,1 , and $10 \mu \mathrm{mol} \mathrm{Zn} \mathrm{L}^{-1}$ supply. Values are means of three independent replicates. Error bars represent $1 \mathrm{SE}$. For each trait, means followed by different letters are significantly different from each other according to two-way ANOVA followed by least significant difference (LSD) multiple comparison $(P<0.05)$. 

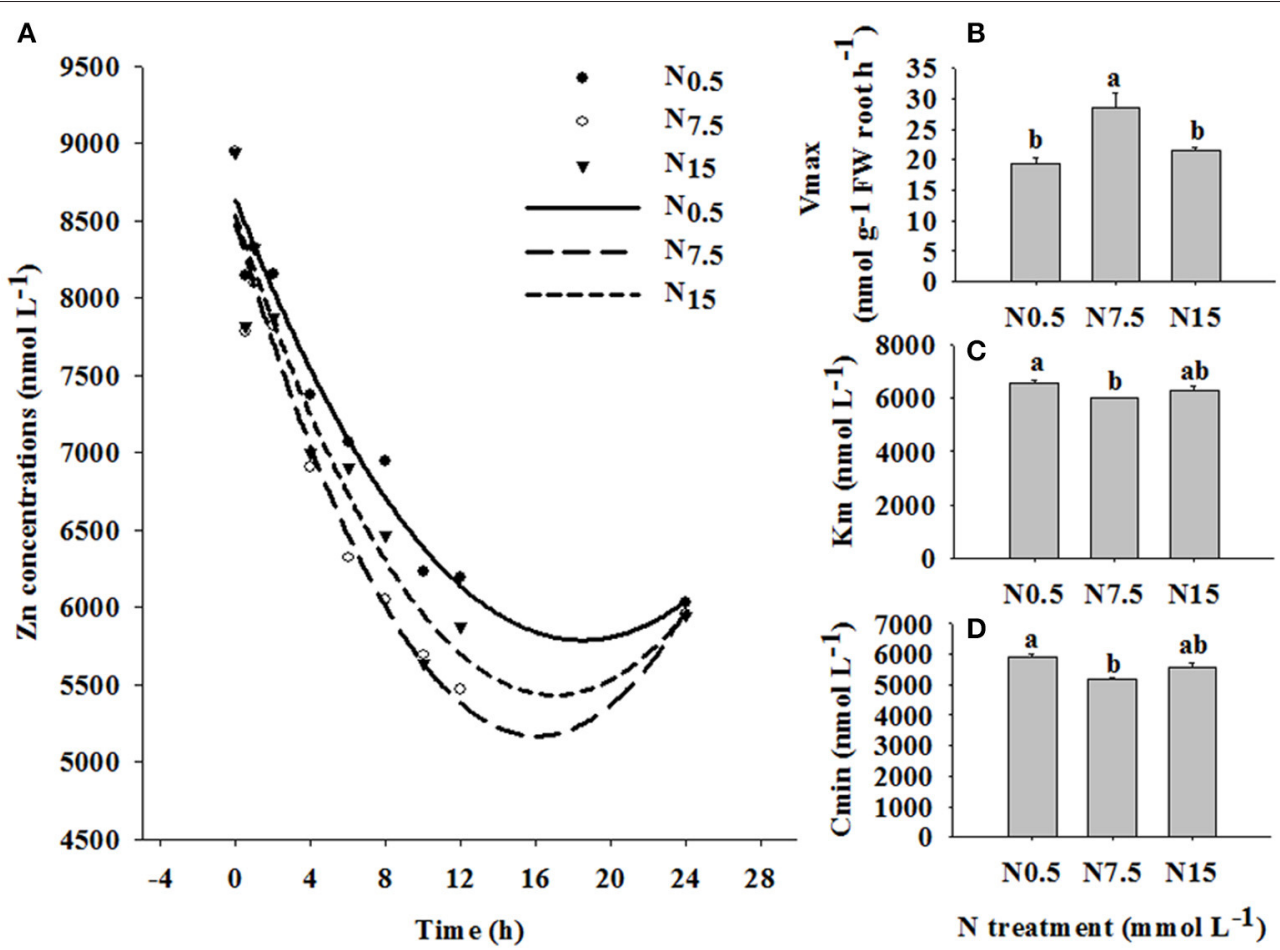

FIGURE 3 | Zinc depletion in solutions containing three winter wheat (Triticum aestivum cv Yunong202) seedlings, grown without Zn and with medium (7.5 mmol $\mathrm{L}^{-1}$ )

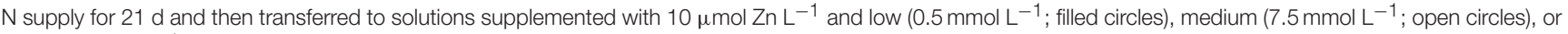
high (15 mmol L ${ }^{-1}$; triangles) $\mathrm{N}$ supply for varying durations (0-24 h). (A): Zn depletion curve, (B): maximum influx rate $V_{\max }$, (C): Michaelis constant $K_{\mathrm{m}}$, (D): minimum equilibrium concentration $C_{\min }$. Values are means of three independent replicates. Error bars represent $1 \mathrm{SE}$. Means followed by different letters are significantly different from each other according to one-way ANOVA followed by least significant difference (LSD) multiple comparison $(P<0.05)$.

TABLE 2 | Root morphology parameters of winter wheat (Triticum aestivum cv Yunong202) seedlings after 7 and $14 \mathrm{~d}$, at $0.5,7.5$, or 15 mmol $\mathrm{NL}^{-1}$ in a nutrient solution with 0,1 , and $10 \mu \mathrm{mol} \mathrm{Zn} \mathrm{L}{ }^{-1}$ supply.

\begin{tabular}{|c|c|c|c|c|c|c|c|c|c|c|c|c|c|}
\hline Growing days & $\mathrm{N}$ supply & \multicolumn{3}{|c|}{ Root length $(\mathrm{cm})$} & \multicolumn{3}{|c|}{ Root surface area $\left(\mathrm{cm}^{2}\right)$} & \multicolumn{3}{|c|}{ Root volume $\left(\mathrm{cm}^{3}\right)$} & \multicolumn{3}{|c|}{ Average root diameter $(\mathrm{cm})$} \\
\hline & $\mathrm{N}_{7.5}$ & 465de & $416 e$ & $550 \mathrm{~b}$ & $41.4 \mathrm{de}$ & 42.9de & $51.2 \mathrm{abc}$ & $0.29 b$ & $0.41 \mathrm{a}$ & $0.38 a$ & $0.30 \mathrm{~b}$ & $0.31 \mathrm{ab}$ & $0.30 \mathrm{~b}$ \\
\hline & $\mathrm{N}_{15}$ & $483 c d$ & 452de & $505 \mathrm{bcd}$ & $47.4 \mathrm{bcd}$ & $41.4 \mathrm{de}$ & $39.9 e$ & $0.37 a$ & $0.29 b$ & $0.29 b$ & $0.32 \mathrm{a}$ & $0.29 b$ & $0.29 b$ \\
\hline $14 d$ & $\mathrm{~N}_{0.5}$ & $1329 a b$ & $1116 \mathrm{bc}$ & $717 \mathrm{e}$ & $122 a$ & 99.8b & $70.2 d$ & $0.88 a$ & $0.79 a b$ & $0.55 \mathrm{e}$ & $0.29 \mathrm{bcd}$ & $0.30 \mathrm{bcd}$ & $0.32 \mathrm{abc}$ \\
\hline
\end{tabular}

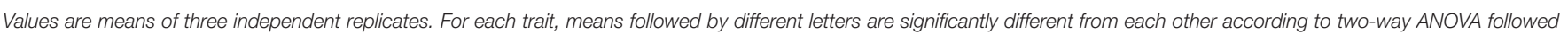
by least significant difference $(L S D)$ multiple comparison $(P<0.05)$.

$\mathrm{Zn}_{10}$ treatment significantly increased root length, root surface area, and root volume in $\mathrm{N}_{0.5}$ and $\mathrm{N}_{7.5}$. The root surface area, volume, and average diameters were significantly increased by $\mathrm{Zn}_{1}$ with the $\mathrm{N}_{0.5}$ application, but decreased by $\mathrm{Zn}_{1}$ and $\mathrm{Zn}_{10}$ in the $\mathrm{N}_{15}$ application. In the 14-d-old seedlings, when compared to $\mathrm{N}_{0.5}$, the $\mathrm{N}_{7.5}$ treatment significantly increased length, surface area, and volume of roots at $\mathrm{Zn}_{10}$, while no pronounced effects appeared on the above root morphology traits in $\mathrm{Zn}_{0}$ and $\mathrm{Zn}_{1}$ (Table 2). The length, surface area, and volume of roots in $\mathrm{N}_{15}$ were lower than those in $\mathrm{N}_{0.5}$ and $\mathrm{N}_{7.5}$ at $\mathrm{Zn}_{0}$ or $\mathrm{Zn}_{1}$. Increasing
Zn supply significantly decreased root length, surface area, and volume at $\mathrm{N}_{0.5}$ or $\mathrm{N}_{15}$. However, $\mathrm{N}$ or $\mathrm{Zn}$ treatment had no significant effect on the average root diameters of winter wheat.

\section{Zn Subcellular Fraction and Distribution}

Zinc concentrations of each tissue fraction were positively affected by both the $\mathrm{N}$ and $\mathrm{Zn}$ treatments, according to the results of two-way ANOVA $(P<0.05$ or $P<0.01$; Table S4). Zinc concentration in each fraction of tissue showed a strong increase with increasing $\mathrm{Zn}$ supply, with the highest in the $\mathrm{Zn}_{10}$ 
treatment. Zinc concentration in cell walls and cell organelles of roots were significantly raised by increasing $\mathrm{N}$ supply at the $\mathrm{Zn}_{10}$ level. At $\mathrm{Zn}_{0}$ and $\mathrm{Zn}_{1}, \mathrm{Zn}$ concentrations in root cell walls and cell organelles increased when $\mathrm{N}$ supply increased from $\mathrm{N}_{0.5}$ to $\mathrm{N}_{7.5}$, but decreased when $\mathrm{N}$ supply increased from $\mathrm{N}_{7.5}$ to $\mathrm{N}_{15}$. The $\mathrm{N}_{7.5}$ treatment had the highest concentrations of $\mathrm{Zn}$ in root cell walls and cell organelles (Table 3 ). An increase in N supply resulted in significant increases in $\mathrm{Zn}$ concentration in the soluble fractions of roots for each $\mathrm{Zn}$ treatment. For stems of winter wheat, the $\mathrm{Zn}$ concentration in cell walls and cell organelles showed a strong decrease in $\mathrm{Zn}_{0}$ and $\mathrm{Zn}_{1}$ treatments with an increase in $\mathrm{N}$ supply. However, Zn concentration in cell walls showed a strong increase in $\mathrm{Zn}_{10}$ treatments with an increase in $\mathrm{N}$ supply; the $\mathrm{N}_{7.5}$ treatment exhibited higher $\mathrm{Zn}$ concentrations in cell organelles than the $\mathrm{N}_{0.5}$ and $\mathrm{N}_{15}$ treatments with the $\mathrm{Zn}_{10}$ application. An increase in $\mathrm{N}$ supply led to higher $\mathrm{Zn}$ concentrations in the soluble fraction in the $\mathrm{Zn}_{1}$ treatment. Zinc concentration in leaf cell walls and cell organelles were increased by an increase in $\mathrm{N}$ supply for each $\mathrm{Zn}$ treatment. An increase in $\mathrm{N}$ supply decreased $\mathrm{Zn}$ concentration in the soluble fraction with $\mathrm{Zn}_{0}$; however, concentration was increased in $\mathrm{Zn}_{10}$.

The proportion of $\mathrm{Zn}$ in the tissues of winter wheat was higher for cell walls than for cell organelles or the soluble fraction, except for a major portion of $\mathrm{Zn}$ that was found in leaf cell organelles in the $\mathrm{Zn}_{0}$ treatment (Figure 4). Two-way ANOVA revealed significant effects of $\mathrm{N}$ and $\mathrm{Zn}$ treatment, and $\mathrm{N} \times \mathrm{Zn}$ interaction on the proportion of $\mathrm{Zn}$ in some factions of tissues $(P<0.05$ or $P$ $<0.01$; Table S5). For each plant part of winter wheat, a decreased proportion of $\mathrm{Zn}$ in cell organelles and an increased proportion of $\mathrm{Zn}$ in cell walls and soluble fractions were found with increasing $\mathrm{Zn}$ supply for each $\mathrm{N}$ treatment (Figure 4). The proportion of $\mathrm{Zn}$ in root cell organelles showed a strong decrease with an increase in $\mathrm{N}$ supply; however, an increased response was observed in root soluble fractions at both $\mathrm{Zn}_{1}$ and $\mathrm{Zn}_{10}$ (Figure 4A). At $\mathrm{Zn}_{0}$ and $\mathrm{Zn}_{1}$, an increase in $\mathrm{N}$ supply significantly increased the proportion of $\mathrm{Zn}$ in stem soluble fractions (Figure 4B). Zinc proportion in leaf cell walls in the $\mathrm{N}_{0.5}$ treatment was higher than that in the $\mathrm{N}_{15}$ or $\mathrm{N}_{7.5}$ treatments at $\mathrm{Zn}_{0}$ and $\mathrm{Zn}_{10}$ (Figure $4 \mathrm{C}$ ). An inconsistent result was found for the proportion of $\mathrm{Zn}$ in leaf cell organelles.

\section{DISCUSSION}

\section{$\mathrm{N}_{7.5}$ Combined with $\mathbf{Z n}_{10}$ Increased $\mathrm{Zn}$ Absorption Through Enhancing Root Growth in Winter Wheat}

An increase in $\mathrm{N}$ supply positively contributed to root absorption and root-to-shoot transport of $\mathrm{Zn}$; these findings concur with the results of Xue et al. (2012). However, the extent of influence of $\mathrm{N}$ supply on $\mathrm{Zn}$ concentration and accumulation in both shoots and roots was determined through differing levels of $\mathrm{Zn}$ application. Under $\mathrm{Zn}_{0}$, an increase in $\mathrm{N}$ supply decreased $\mathrm{Zn}$ concentrations in the shoots and roots of winter wheat (Figures 1A,B), which was attributed to a dilution effect caused by an increase in growth as a result of increased $\mathrm{N}$ availability (Alloway, 2008). Furthermore, $\mathrm{N}$ supply did not significantly contribute to $\mathrm{Zn}$ accumulation without an additional $\mathrm{Zn}$ supply (Figures 1C,D), which might be due to low concentrations of $\mathrm{Zn}$ in the solution, which in turn limited $\mathrm{Zn}$ absorption into the roots. For the $\mathrm{Zn}_{1}$ treatment, an increase in $\mathrm{N}$ supply increased $\mathrm{Zn}$ concentration and accumulation in shoots; however, it had no obvious effect in roots (Figure 1). This suggests that an increase in $\mathrm{N}$ supply positively impacted on the root-to-shoot transport of $\mathrm{Zn}$ and further $\mathrm{Zn}$ accumulation in shoots in $\mathrm{Zn}_{1}$. Enhancement of $\mathrm{Zn}$ concentration following an increase in $\mathrm{N}$ supply has been suggested due to the growth enhancing effect of $\mathrm{N}$ (Aciksoz et al., 2011). However, Xue et al. (2012) report that an increase in shoot growth caused by increased $\mathrm{N}$ supply cannot be the major reason for an increase in shoot $\mathrm{Zn}$ content. Our results suggested that the increased $\mathrm{Zn}$ concentration in shoots might be partially related to the enhanced growth that took place following an increase in $\mathrm{N}$ supply. On the one hand, $\mathrm{Zn}$ concentration and accumulation in roots were not affected by the $\mathrm{N}_{15}$ treatment (Figures 1B,D),

TABLE 3 | Subcellular fractionation of $\mathrm{Zn}$ in tissues of winter wheat (Triticum aestivum cv Yunong202) seedlings, grown at 0.5, 7.5, or 15 mmol N L ${ }^{-1}$ in a nutrient solution with 0,1 , and $10 \mu \mathrm{mol} \mathrm{Zn} \mathrm{L^{-1 }}$ supply for $21 \mathrm{~d}$.

\begin{tabular}{|c|c|c|c|c|c|c|c|c|c|c|}
\hline \multirow[t]{2}{*}{ Tissues } & \multirow[t]{2}{*}{ N supply } & \multicolumn{3}{|c|}{$\begin{array}{l}\text { Cell wall fraction } \\
\left.\text { (mg kg }{ }^{-1} \mathrm{FW}\right)\end{array}$} & \multicolumn{3}{|c|}{$\begin{array}{l}\text { Cell organelle fraction } \\
\qquad\left(\mathrm{mg} \mathrm{kg}^{-1} \mathrm{FW}\right)\end{array}$} & \multicolumn{3}{|c|}{$\begin{array}{l}\text { Soluble fraction } \\
\left(\mathrm{mg} \mathrm{kg}^{-1} \mathrm{FW}\right)\end{array}$} \\
\hline & & $Z_{0}$ & $\mathrm{Zn}_{1}$ & $\mathrm{Zn}_{10}$ & $\mathrm{Zn}_{0}$ & $\mathrm{Zn}_{1}$ & $\mathrm{Zn}_{10}$ & $\mathrm{Zn}_{0}$ & $\mathrm{Zn}_{1}$ & $\mathrm{Zn}_{10}$ \\
\hline \multirow[t]{3}{*}{ Root } & $\mathrm{N}_{0.5}$ & $6.30 \mathrm{bc}$ & $9.42 \mathrm{~b}$ & $11.1 b$ & $1.83 e$ & $3.85 \mathrm{c}$ & $7.15 b$ & 0.50 e & $0.67 \mathrm{de}$ & $2.71 \mathrm{c}$ \\
\hline & $\mathrm{N}_{7.5}$ & $10.6 b$ & $8.35 \mathrm{bc}$ & $21.0 a$ & $2.54 \mathrm{de}$ & $3.78 \mathrm{~cd}$ & $13.0 a$ & 0.94de & 1.43de & $11.3 b$ \\
\hline & $\mathrm{N}_{15}$ & $4.52 \mathrm{c}$ & $7.16 \mathrm{bc}$ & $17.8 \mathrm{a}$ & $1.49 e$ & $1.72 \mathrm{e}$ & $8.11 b$ & $1.55 d$ & $3.31 c$ & $13.1 a$ \\
\hline \multirow[t]{3}{*}{ Stem } & $\mathrm{N}_{0.5}$ & $10.7 \mathrm{bc}$ & $20.9 a$ & $9.26 c$ & $4.50 c$ & $6.14 b$ & $6.38 b$ & 1.10de & $1.75 c$ & $3.41 \mathrm{a}$ \\
\hline & $\mathrm{N}_{7.5}$ & $11.4 \mathrm{bc}$ & $11.4 \mathrm{bc}$ & $11.9 \mathrm{bc}$ & $2.75 d$ & $6.22 \mathrm{~b}$ & $8.45 a$ & $1.24 \mathrm{cde}$ & $2.40 b$ & $3.92 \mathrm{a}$ \\
\hline & $\mathrm{N}_{15}$ & $3.27 d$ & $9.11 \mathrm{c}$ & $13.1 b$ & $2.02 d$ & $4.69 c$ & $6.87 b$ & $0.65 e$ & $1.63 \mathrm{~cd}$ & $3.94 a$ \\
\hline \multirow[t]{3}{*}{ Leaf } & $\mathrm{N}_{0.5}$ & $1.91 \mathrm{de}$ & $2.88 d$ & $9.54 \mathrm{ab}$ & $2.13 \mathrm{de}$ & $1.40 \mathrm{e}$ & 2.29de & $0.57 \mathrm{bc}$ & $0.73 b c$ & $0.80 \mathrm{bc}$ \\
\hline & $\mathrm{N}_{7.5}$ & $1.64 \mathrm{e}$ & $4.96 c$ & $9.08 b$ & $7.90 a$ & $2.12 \mathrm{de}$ & $5.74 b c$ & $0.52 \mathrm{bc}$ & $1.41 b c$ & $3.15 a$ \\
\hline & $\mathrm{N}_{15}$ & 2.63de & $4.26 c$ & $10.3 a$ & $6.73 a b$ & $1.20 \mathrm{e}$ & $4.03 \mathrm{~cd}$ & $0.25 c$ & $1.56 b$ & $2.96 \mathrm{a}$ \\
\hline
\end{tabular}

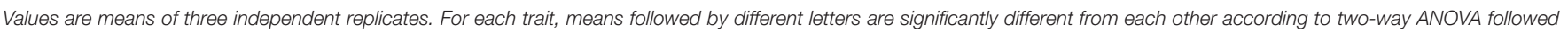
by least significant difference $(L S D)$ multiple comparison $(P<0.05)$. 


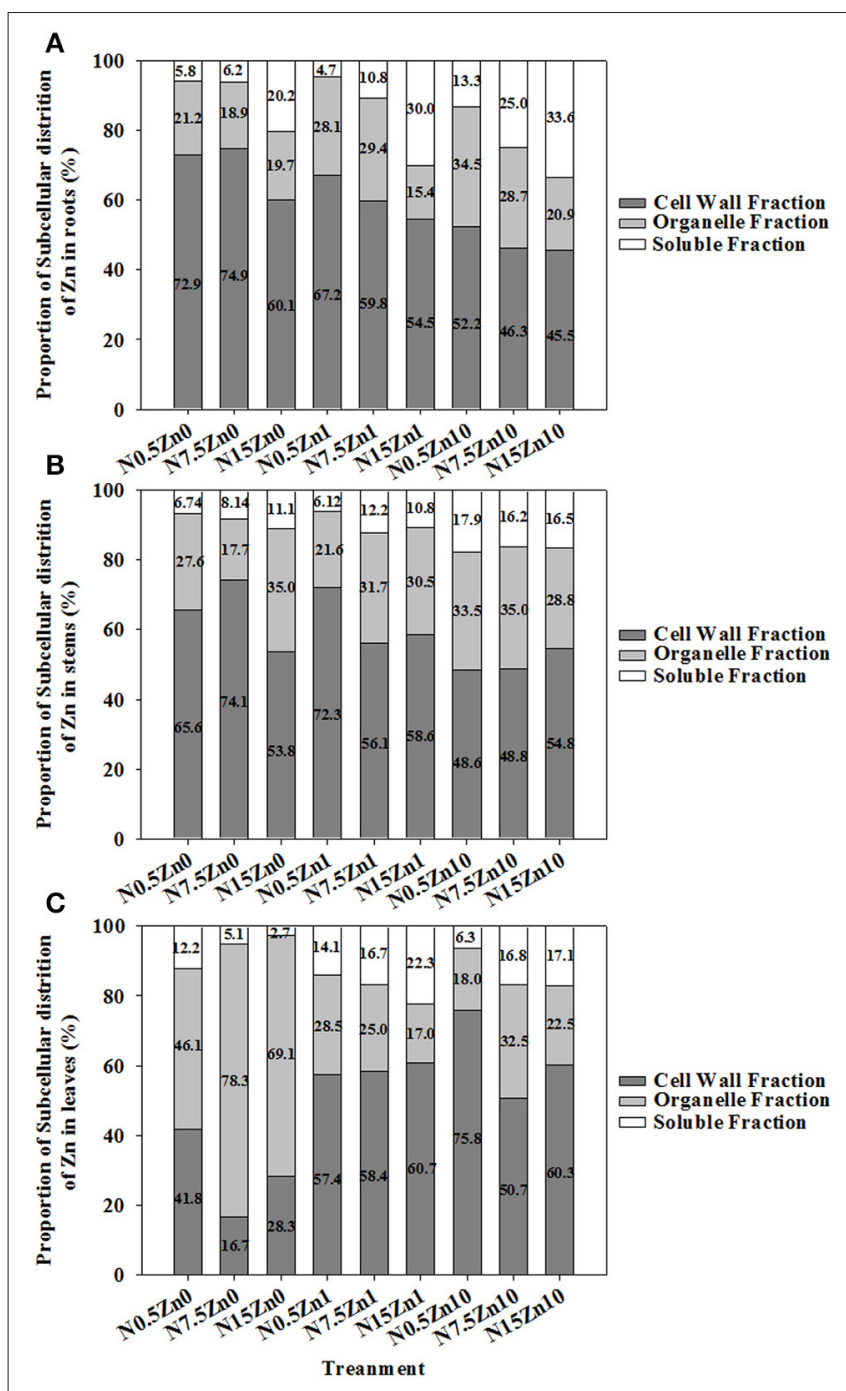

FIGURE 4 | Subcellular distribution of $Z n$ as a percent of total $Z n$ in roots (A), stems (B), and leaves (C) of winter wheat (Triticum aestivum cv Yunong202) seedlings, grown at $0.5,7.5$, or $15 \mathrm{mmol} \mathrm{N} \mathrm{L}^{-1}$ in a nutrient solution with 0,1 , and $10 \mu \mathrm{mol} Z \mathrm{n} \mathrm{L}^{-1}$ supply for $21 \mathrm{~d}$. Subcellular distribution of $\mathrm{Zn}$ (\%) was calculated via dividing the fraction by the total of fractions in each tissue and multiplying the quotient by 100 . Values are means of three independent replicates. though it significantly increased root dry weight (Table 1). On the other hand, dry weight and Zn concentrations of shoots were increased, and then $\mathrm{Zn}$ accumulation was enhanced by $\mathrm{N}$ supply (Table 1; Figures 1A,C). This might be because N supply enhanced $\mathrm{Zn}$ transfer from roots to shoots, even when a trace amount of $\mathrm{Zn}$ was in the solution. For $\mathrm{Zn}_{10}$, an increase in $\mathrm{N}$ supply increased $\mathrm{Zn}$ concentration and accumulation in both shoots and roots of winter wheat (Figure 1). These results showed that the positive effect of increasing $\mathrm{N}$ supply on $\mathrm{Zn}$ absorption and root-to-shoot transport became more and more remarkable as $\mathrm{Zn}$ application increased up to a high level. The results revealed that the combination of adequate or near-adequate $\mathrm{N}$ supply $\left(\mathrm{N}_{7.5}\right.$ and $\left.\mathrm{N}_{15}\right)$ with high $\mathrm{Zn}$ supply $\left(\mathrm{Zn}_{10}\right)$ was most beneficial to absorption and root-to-shoot transport of $\mathrm{Zn}$ than applications of $\mathrm{N}$ or $\mathrm{Zn}$ alone. Our previous study showed that $\mathrm{N}$ combined with a high $\mathrm{Zn}\left(30 \mathrm{~kg} \mathrm{Zn} \mathrm{ha}^{-1}\right)$ treatment enhanced $\mathrm{Zn}$ absorption and translocation, and increased $\mathrm{Zn}$ accumulation in winter wheat grain that was grown in Zn-deficient soil (Zhao et al., 2016). Thus, in order to increase $\mathrm{Zn}$ concentration in wheat grain cultured on $\mathrm{Zn}$-deficient soils, a combination of adequate $\mathrm{N}$ with high $\mathrm{Zn}$ application is a better choice.

The time-course depletion experiment also revealed the enhanced effect of increasing $\mathrm{N}$ supply on the $\mathrm{Zn}$ absorption kinetics in winter wheat. In the $\mathrm{Zn}_{10}$ treatment, the depletion of $\mathrm{Zn}$ from solution was significantly increased by $\mathrm{N}_{7.5}$ (Figure 3A). This suggests that the $\mathrm{N}_{7.5}$ treatment enhanced $\mathrm{Zn}$ removal from solution, and absorption through at root surface. The value of $V_{\max }$ was higher, and the values of $K_{\mathrm{m}}$ and $C_{\min }$ were lower for the $\mathrm{N}_{7.5}$ treatment, compared to the $\mathrm{N}_{0.5}$ and $\mathrm{N}_{15}$ treatments (Figures 3B-D). Therefore, enhanced $\mathrm{Zn}$ absorption in the $\mathrm{N}_{7.5}$ treatment might be related to the membrane transport systems regulating $\mathrm{Zn}$ absorption and transport processes. Erenoglu et al. (2011) also report that increasing $\mathrm{N}$ supply significantly enhances root $\mathrm{Zn}$ uptake, which is due to the $\mathrm{N}$ enhanced abundance of transporters, including ZIPs such as iron-regulated transporter (IRT). Generally, the expression of transporters related to nutrient uptake is quick in response to the change of environmental factors (Nie et al., 2014), which explains why $\mathrm{N}$ supply over only $24 \mathrm{~h}$ was able to change $\mathrm{Zn}$ absorption in our study. Thus, investigating the effect of $\mathrm{N}$ supply on the transporter expression related to $\mathrm{Zn}$ absorption and translocation in winter wheat is deserving of further research.

In the current study, when $\mathrm{N}$ increased from $\mathrm{N}_{7.5}$ to $\mathrm{N}_{15}$, no further increase in $\mathrm{Zn}$ accumulation in shoots or roots was observed. Moreover, the $\mathrm{N}_{7.5}$ treatment significantly increased $\mathrm{Zn}$ concentrations in shoots and roots under $\mathrm{Zn}_{1}$ (shoots: $\mathrm{N}_{7.5}$ $34.11 \mathrm{mg} \mathrm{kg}{ }^{-1}>\mathrm{N}_{15} 23.40 \mathrm{mg} \mathrm{kg}{ }^{-1}$; roots: $\mathrm{N}_{7.5} 48.26 \mathrm{mg}$ $\mathrm{kg}^{-1}>\mathrm{N}_{15} 33.71 \mathrm{mg} \mathrm{kg}^{-1}$ ) and $\mathrm{Zn}_{10}$ treatments (shoot: $\mathrm{N}_{7.5}$ $105.51 \mathrm{mg} \mathrm{kg}^{-1}>\mathrm{N}_{15} 91.37 \mathrm{mg} \mathrm{kg}^{-1}$; root: $\mathrm{N}_{7.5} 310.61 \mathrm{mg} \mathrm{kg}{ }^{-1}$ $>\mathrm{N}_{15} 236.07 \mathrm{mg} \mathrm{kg}^{-1}$; Figure 1). Similar results were obtained for differences in $\mathrm{Zn}$ depletion in solution and the values of $V_{\max }$, $K_{\mathrm{m}}$, and $C_{\text {min }}$ between the $\mathrm{N}_{7.5}$ and $\mathrm{N}_{15}$ treatments (Figure 3). These results might be because the plants already had sufficient Zn under the $\mathrm{N}_{7.5}$ treatment.

Root morphology (root length, surface area, and volume) can reflect the growth conditions of plant roots as it is influenced by environmental factors (Fageria and Moreira, 2011). Our results showed that $\mathrm{N}_{7.5}$ could promote root development by increasing root length, surface area and volume at the $\mathrm{Zn}_{10}$ treatment. Xue et al. (2014) pointed that greater root lengths and surface area due to $\mathrm{N}$ application might contribute to the increase in $\mathrm{Zn}$ uptake of roots in winter wheat. Therefore, cosupply of $\mathrm{N}$ and $\mathrm{Zn}$ could stimulate roots development might be one reason why $\mathrm{Zn}$ absorption was enhanced. With a further increase in $\mathrm{N}$ supply to $\mathrm{N}_{15}$, root development of 7 - and 14d-old seedlings was inhibited, compared to the $\mathrm{N}_{0.5}$ treatment. However, compared to $\mathrm{N}_{0.5}, \mathrm{~N}_{15}$ inhibited the growth of roots but still enhanced $\mathrm{Zn}$ absorption and accumulation in winter wheat, suggesting that interference with the $\mathrm{Zn}$ membrane 
transport process might be another reason for increasing $\mathrm{Zn}$ absorption following high rates of $\mathrm{N}$ application (Erenoglu et al., 2011).

In short, adequate $\mathrm{N}$ combined with high $\mathrm{Zn}$ supply increased $V_{\max }$ and decreased $K_{\mathrm{m}}$ and $C_{\mathrm{min}}$, and affected $\mathrm{Zn}$ membrane transport to enhance plant ability to absorb $\mathrm{Zn}$. On the other hand, it increased root length, root surface area and root volume, and promoted root growth and development to enhance the absorption of $\mathrm{Zn}$ from soil solution.

\section{An Increase in N Supply Was Beneficial to a Balanced Distribution of $\mathrm{Zn}$ between Subcellular Fractions}

In our study, the subcellular distribution of $\mathrm{Zn}$ was higher in cell walls than in cell organelles or soluble fractions in most treatments, except that a greater amount of $\mathrm{Zn}$ was present in the cell organelles of leaves in $\mathrm{Zn}_{0}$ (Table 3; Figure 4). It was speculated that winter wheat could transfer more $\mathrm{Zn}$ into cell organelles to maintain normal metabolism under Zn deficiency. Our results were consistent with results of Pan et al. (2016), who noted that, at toxic levels, the majority of $\mathrm{Zn}$ was localized in cell walls. This indicated that the cell wall was the primary site of $\mathrm{Zn}$ storage, whether $\mathrm{Zn}$ was present at sufficient or excessive levels in the soil.

An increase in $\mathrm{N}$ supply had diverse effects on the subcellular distribution of $\mathrm{Zn}$ in different tissues or at different levels of $\mathrm{Zn}$ application. In the $\mathrm{Zn}_{0}$ and $\mathrm{Zn}_{1}$ treatments, $\mathrm{Zn}$ distribution in root cell walls and cell organelles were significantly decreased by an increase in $\mathrm{N}$ supply (Table 3; Figure 4A). In contrast, an increase in $\mathrm{N}$ supply enhanced $\mathrm{Zn}$ distribution in the root soluble fraction. A decreased distribution of $\mathrm{Zn}$ in cell walls of roots and stems through an increase in $\mathrm{N}$ supply was beneficial to $\mathrm{Zn}$ translocation to shoots, as the accumulation of trace metals in cell walls would inhibit migration into the protoplast (Krzesłowska, 2011). An increase in $\mathrm{N}$ supply significantly increased $\mathrm{Zn}$ concentrations in each subcellular fraction in the $\mathrm{Zn}_{10}$ treatment (Table 3), which was related to the increased $\mathrm{Zn}$ concentrations seen with the high $\mathrm{Zn}$ treatment. However, an increase in $\mathrm{N}$ supply still decreased $\mathrm{Zn}$ distribution in root cell walls and cell organelles, while an increase occurred in root soluble fractions (Figure 4A). In leaves under the $\mathrm{Zn}_{0}$ treatment, an increase in $\mathrm{N}$ supply decreased the portion of $\mathrm{Zn}$ in cell walls and in the soluble fraction, and increased the portion of $\mathrm{Zn}$ in cell organelles (Figure 4C). This suggested that an increase in $\mathrm{N}$ supply could enhance $\mathrm{Zn}$ transport to cell organelles, thus maintaining a normal exchange of materials and signals between cells and the external environment when $\mathrm{Zn}$ is deficient (Hacisalihoglu and Kochian, 2003; Alloway, 2008). In $\mathrm{Zn}_{1}$ and $\mathrm{Zn}_{10}, \mathrm{Zn}$ concentrations, and distribution in soluble fractions

\section{REFERENCES}

Aciksoz, S., Yazici, A., Ozturk, L., and Cakmak, I. (2011). Biofortification of wheat with iron through soil and foliar application of nitrogen and iron fertilizers. Plant Soil 349, 215-225. doi: 10.1007/s11104-011-0863-2

Alloway, B. J. (2008). Zinc in Soils and Crop Nutrition, 2nd Edn. Brussels; Paris: IZA and IFA. were increased by an increase in $\mathrm{N}$ supply, indicating that $\mathrm{N}$ could enhance the compartmentalization of $\mathrm{Zn}$ in vacuoles, which are the main compartment for the soluble fraction (Weigel and Jäger, 1980).

\section{CONCLUSIONS}

This study demonstrated that an adequate $\mathrm{N}$ supply enhanced $\mathrm{Zn}$ absorption and $\mathrm{Zn}$ accumulation in shoots. We found significant and positive correlations between $\mathrm{N}$ and $\mathrm{Zn}$ concentrations and accumulation. The results suggested that increased $\mathrm{N}$ supply positively contributed to root absorption and root-to-shoot transport of $\mathrm{Zn}$. The $\mathrm{N}_{7.5}$ treatment significantly increased the value of $V_{\max }$, while it decreased the values of $K_{\mathrm{m}}$ and $C_{\min }$. A combination of $\mathrm{N}_{7.5}$ and $\mathrm{Zn}_{10}$ treatments stimulated root development by increasing root length, surface area, and volume of 14-d-old seedlings, and led to a change in root size from 7 to $14 \mathrm{~d}$. This indicated that the positive effects of a combination of $\mathrm{N}_{7.5}$ and $\mathrm{Zn}_{10}$ on high affinity between the $\mathrm{Zn}$ uptake transporters and stimulated root development might contribute to $\mathrm{Zn}$ absorption and its accumulation in winter wheat. In roots, $\mathrm{Zn}$ distribution in cell walls and cell organelles was significantly decreased, and that in soluble fractions was increased by an increase in $\mathrm{N}$ supply. By contrast, in leaves, an increase in $\mathrm{N}$ supply significantly decreased $\mathrm{Zn}$ in cell walls and soluble fractions, and increased $\mathrm{Zn}$ in cell organelles under $\mathrm{Zn}_{0}$; however, it increased $\mathrm{Zn}$ distribution in the soluble fractions of $\mathrm{Zn}_{1}$ and $\mathrm{Zn}_{10}$. These results suggest that an increase in $\mathrm{N}$ supply enhanced $\mathrm{Zn}$ translocation to shoots, thus maintaining normal metabolism in winter wheat.

\section{AUTHOR CONTRIBUTIONS}

HL conceived and designed the experiments. JW and JL performed the experiments. $\mathrm{PZ}$ analyzed the data. $\mathrm{ZN}$ wrote the paper.

\section{ACKNOWLEDGMENTS}

This study was supported by the National Natural Science Foundation of China (Program Nos. 41501311; 41201286) and the Key Scientific Research Project for the Universities of Henan Province (Program No. 17A210002).

\section{SUPPLEMENTARY MATERIAL}

The Supplementary Material for this article can be found online at: http://journal.frontiersin.org/article/10.3389/fpls.2017. 01435/full\#supplementary-material

Barber, S. A. (1979). "Growth requirements for nutrients in relation to demand at the root surface," in The Soil-Root Interface, eds J. L. Harley and R. S. Russell (London; New York, NY; San Francisco, CA: Academic Press), 5-20.

Bouis, H. E. (2003). Micronutrient fortification of plants through plant breeding: can it improve nutrition in man at low cost? Proc. Nutr. Soc. 62, 403-411. doi: 10.1079/PNS2003262 
Cakmak, I. (2008). Enrichment of cereal grains with zinc: agronomic or genetic biofortification? Plant Soil 302, 1-17. doi: 10.1007/s11104-007-9466-3

Cakmak, I., Pfeiffer, W. H., and McClafferty, B. (2010). Review: biofortification of durum wheat with zinc and iron. Cereal Chem. 87, 10-20. doi: 10.1094/CCHEM-87-1-0010

Chardonnens, A. N., Wilma, M., Vellinga, S., Schat, H., Verkleij, J. A., and Ernst, W. H. (1999). Allocation patterns of zinc and cadmium in heavy metal tolerant and sensitive Silene vulgaris. J. Plant Physiol. 155, 778-787. doi: 10.1016/S0176-1617(99)80096-0

Erenoglu, E. B., Kutman, U. B., Ceylan, Y., Yildiz, B., and Cakmak, I. (2011). Improved nitrogen nutrition enhances root uptake, root-to-shoot translocation and remobilization of zinc $(65 \mathrm{Zn})$ in wheat. New Phytol. 189, 438-448. doi: 10.1111/j.1469-8137.2010.03488.x

Fageria, N., and Moreira, A. (2011). The role of mineral nutrition on root growth of crop plants. Adv. Agron. 110, 251-331. doi: 10.1016/B978-0-12-385531-2.00004-9

Guo, J., Liu, X., Zhang, Y., Shen, J., Han, W., Zhang, W., et al. (2010). Significant acidification in major Chinese croplands. Science 327, 1008-1010. doi: $10.1126 /$ science. 1182570

Hacisalihoglu, G., and Kochian, L. V. (2003). How do some plants tolerate low levels of soil zinc? Mechanisms of zinc efficiency in crop plants. New Phytol. 159, 341-350. doi: 10.1046/j.1469-8137.2003.00826.x

Jiang, T. H., Zheng, S. J., Shi, J. Q., Hu, A. T., and Shi, R. H. (1995). Several considerations in kinetic research on nutrition uptake by plants. Plant Nutr. Ferti. Sci. 1, 11-17 (in Chinese with English abstract).

Krzesłowska, M. (2011). The cell wall in plant cell response to trace metals: polysaccharide remodeling and its role in defense strategy. Acta Physiol. Plant. 33, 35-51. doi: 10.1007/s11738-010-0581-z

Kutman, U. B., Yildiz, B., Ozturk, L., and Cakmak, I. (2010). Biofortification of durum wheat with zinc through soil and foliar applications of nitrogen. Cereal Chem. 87, 1-9. doi: 10.1094/CCHEM-87-1-0001

Le, C., Zha, Y., Li, Y., Sun, D., Lu, H., and Yin, B. (2010). Eutrophication of lake waters in China: cost, causes, and control. Environ. Manage. 45, 662-668. doi: 10.1007/s00267-010-9440-3

Li, M., Wang, S. X., Tian, X. H., Zhao, J. H., Li, H. Y., Guo, C. H., et al. (2015). $\mathrm{Zn}$ distribution and bioavailability in whole grain and grain fractions of winter wheat as affected by applications of soil $\mathrm{N}$ and foliar $\mathrm{Zn}$ combined with $\mathrm{N}$ or $\mathrm{P}$. J. Cereal Sci. 61, 26-32. doi: 10.1016/j.jcs.2014.09.009

Li, T. Q., Yang, X. E., Yang, J. Y., and He, Z. L. (2006). Zn accumulation and subcellular distribution in the Zn hyperaccumulator Sedum alfredii Hance. Pedosphere 16, 616-623. doi: 10.1016/S1002-0160(06)60095-7

Liu, Z. (1994). Regularities of content and distribution of zinc in soils of China. Sci. Agric. Sin. 27, 30-37 (in Chinese with English abstract).

Ma, G., Jin, Y., Li, Y., Zhai, F., Kok, F. J., Jacobsen, E., et al. (2008). Iron and zinc deficiencies in China: what is a feasible and costeffective strategy? Public Health Nutr. 11, 632-638. doi: 10.1017/S136898000 7001085

Nie, Z. J., Hu, C. X., Liu, H. E., Tan, Q. L., and Sun, X. C. (2014). Differential expression of molybdenum transport and assimilation genes between two winter wheat cultivars (Triticum aestivum). Plant Physiol. Biochem. 82, 27-33. doi: 10.1016/j.plaphy.2014.05.002

Pan, X., Chen, G., Shi, C., Chai, M., Liu, J., Cheng, S., et al. (2016). Effects of $\mathrm{Zn}$ stress on growth, $\mathrm{Zn}$ accumulation, translocation, and subcellular distribution of Spartina alterniflora Loisel. Clean Soil Air Water 44, 579-585. doi: $10.1002 /$ clen.201400288
Peleg, Z., Saranga, Y., Yazici, A., Fahima, T., Ozturk, L., and Cakmak, I. (2008). Grain zinc, iron and protein concentrations and zinc-efficiency in wild emmer wheat under contrasting irrigation regimes. Plant Soil 306, 57-67. doi: 10.1007/s11104-007-9417-z

Pfeiffer, W. H., and McClafferty, B. (2007). Harvest Plus: breeding crops for better nutrition. Crop Sci. 47(Suppl. 3), S88-S105. doi: 10.2135/cropsci2007.09.0020IPBS

Rathore, V., Bajaj, Y., and Wittwer, S. (1972). Subcellular localization of zinc and calcium in bean (Phaseolus vulgaris L.) tissues. Plant Physiol. 49, 207-211. doi: $10.1104 /$ pp.49.2.207

Weigel, H. J., and Jäger, H. J. (1980). Subcellular distribution and chemical form of cadmium in bean plants. Plant Physiol. 65, 480-482. doi: 10.1104/pp.65.3.480

Welch, R. M., and Graham, R. D. (2004). Breeding for micronutrients in staple food crops from a human nutrition perspective. J. Exp. Bot. 55, 353-364. doi: $10.1093 /$ jxb/erh064

Whatley, F., Ordin, L., and Arnon, D. I. (1951). Distribution of micronutrient metals in leaves and chloroplast fragments. Plant Physiol. 26:414. doi: $10.1104 /$ pp.26.2.414

White, P. J., and Broadley, M. R. (2009). Biofortification of crops with seven mineral elements often lacking in human diets-iron, zinc, copper, calcium, magnesium, selenium and iodine. New Phytol. 182, 49-84. doi: 10.1111/j.1469-8137.2008.02738.x

Xue, Y. F., Yue, S. C., Zhang, Y. Q., Cui, Z. L., Chen, X. P., Yang, F. C., et al. (2012). Grain and shoot zinc accumulation in winter wheat affected by nitrogen management. Plant Soil 361, 153-163. doi: 10.1007/s11104-012-1510-2

Xue, Y. F., Zhang, W., Liu, D. Y., Yue, S. C., Cui, Z. L., Chen, X. P., et al. (2014). Effects of nitrogen management on root morphology and zinc translocation from root to shoot of winter wheat in the field. Field Crop. Res. 161, 38-45. doi: 10.1016/j.fcr.2014.01.009

Yang, J., and Zhang, J. (2006). Grain filling of cereals under soil drying. New Phytol. 169, 223-236. doi: 10.1111/j.1469-8137.2005.01597.x

Zhao, P., Yang, F., Sui, F., and Wang, Q. (2013). Effect of combined application of $\mathrm{Zn}$ and $\mathrm{N}$ fertilizers on nitrogen use, grain yield and protein content in winter wheat. J. China Agric. Univ. 18, 28-33. doi: 10.3321/j.issn:1007-4333.2013.03.004. (Chinese with English abstract).

Zhao, P., Yang, F., Sui, F., Wang, Q., and Liu, H. (2016). Effect of nitrogen fertilizers on zinc absorption and translocation in winter wheat. J. Plant Nutr. 39, 1311-1318. doi: 10.1080/01904167.2015.1106560

Zheng, X., Han, S., Huang, Y., Wang, Y., and Wang, M. (2004). Re-quantifying the emission factors based on field measurements and estimating the direct N2O emission from Chinese croplands. Global Biogeochem. Cycles 18, 60-70. doi: 10.1029/2003GB002167

Zhuang, Q. S. (2003). Chinese Wheat Improvement and Pedigree Analysis. Beijing: China Agriculture Press.

Conflict of Interest Statement: The authors declare that the research was conducted in the absence of any commercial or financial relationships that could be construed as a potential conflict of interest.

Copyright (c) 2017 Nie, Zhao, Wang, Li and Liu. This is an open-access article distributed under the terms of the Creative Commons Attribution License (CC BY). The use, distribution or reproduction in other forums is permitted, provided the original author(s) or licensor are credited and that the original publication in this journal is cited, in accordance with accepted academic practice. No use, distribution or reproduction is permitted which does not comply with these terms. 